\title{
Analysis of the harmful influence of parasiteismic vibrations using the example of a failure in the building structure of a school gymnasium
}

\author{
Wiesław Liszewski ${ }^{1}$
}

\section{ABSTRACT:}

This article describes, based on the failure of a public utility building structure, the issues related to the destructive impact of vibrations on the ground in connection with the load-bearing structure of the facility. An external source of wave propagation was identified, located in the immediate vicinity of the analyzed building. Additionally, errors in the interpretation of the behavior of the structure during its operation were presented by performing ineffective construction works related to the attempt to strengthen the ground on which the school sports hall was directly erected. On the basis of the analysis of archival materials and additional tests, the necessary scope of repair works necessary to be performed on the site was determined, along with guidelines for the implementation of the diaphragm in the form of a ground vibro-isolating screen, aimed at minimizing the impact of parasiteismic impacts on the public building.

\section{KEYWORDS:}

vibrations; wave propagation; wave attenuation; vibration isolation

\section{Introduction}

In the building of the gymnasium (and the connector) at a primary school located in the Myszków district, numerous scratches on the walls were found after several years of operation, which resulted in the partial decommissioning of the facility.

The facility was built in the 1990s. The subject, a gymnasium with windows on the south side with ground-floor social facilities located on the north side and dimensions in the horizontal projection of about $25 \mathrm{~m} \times 22 \mathrm{~m}$, is a standalone building, without a basement, connected to the didactic segment by means of a one-story connector. Between the hall and the back room there is a corridor above which there is a gallery for viewers.

The parcel of land on which the gymnasium building is located is a fully developed plot of land with infrastructure and access to a voivodeship road located in the immediate vicinity. The terrain was created as a result of leveling, where construction embankments were to be built in the place of a foundation for the building.

During a periodic inspection of the facility, as part of Art. $62 \mathrm{sec} .1$ point 1 point a of the Act of July 7, 1994 - Construction Law (Journal of Laws of 2006 No. 156, item 1118, as amended), it was found that the building of the school gymnasium was damaged in the form of numerous scratches and cracks. As a consequence, the technical services commissioned field tests and the development of a geotechnical opinion to determine the actual foundation conditions for the building. Four test holes were made (in the corners of the building) to determine the physical and mechanical properties of the soil, as well as probing to determine the degree of soil compaction.

1 Czestochowa University of Technology, Faculty of Civil Engineering, ul. Akademicka 3, 42-218 Częstochowa, e-mail: wieslaw.liszewski@.pcz.pl, orcid id: 0000-0002-3997-6436 


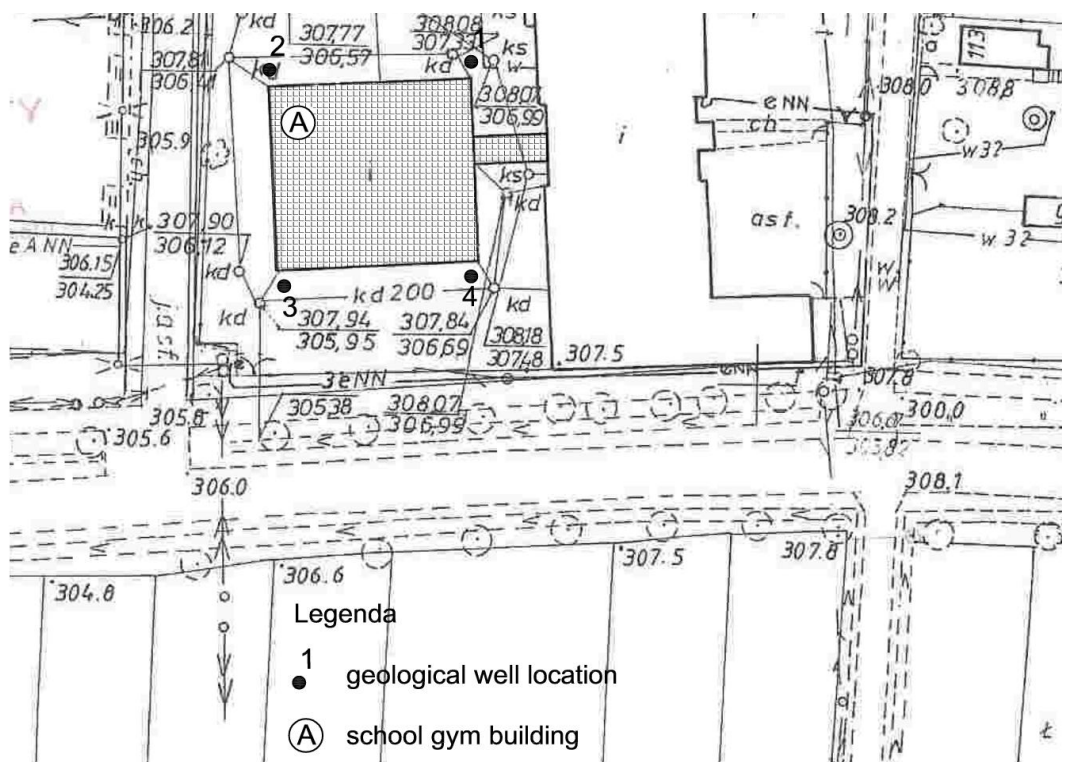

Fig. 1. Location of geotechnical drilling

After the tests, it was found that under some of the building's foundations (western and southern parts) there were loose embankments $\left(l_{D}=0.30 \div 0.50\right)$ with a thickness of up to $1.1 \mathrm{~m}$. The embankments consist of sand, soil, construction debris and organic sediment. Under the remaining part, there are fine and medium-compacted sands as well as sandy and dusty loams in a hard-plastic and semi-compact state. The bearing layers are sloped to the south-west. Gravel and compacted gravel lie deeper. The discovered foundation conditions were defined as varied and generally unfavorable. Due to the lack of any data on the method of preparing the embankments, the most reliable variant was the construction of the embankments in an uncontrolled manner.

The conclusions from the study indicated that after the ground was loaded with the building, its secondary consolidation and uncontrolled settlement took place. The amount of subsidence was determined to be varied due to the variable thickness of the embankments and the varying degree of compaction. In addition, the possibility of infiltrating water runoff (southwest on the clay ceiling), which resulted in the removal of the smallest particles from outside the building outline, was indicated. This also caused additional loosening of the soil. It was shown that such foundation conditions had a direct impact on the settlement: the maximum in the south-west corner, and the minimum in the line of the eastern wall. According to opinion, this resulted in the deflection of the building (convex curve) and, consequently, the creation of significant shear and tensile forces in the walls of the building. Consequently, as a recommendation, in order to stabilize the ground, micropiling of the building foundation was performed.

\section{Description of the main structural elements of the building}

Despite the repair works carried out, including the strengthening of the subsoil by means of micropiling, the condition of the object showed further deterioration over time, which was revealed by new scratches and increasing cracks.

The building was founded on reinforced concrete footings and foundation footings, at a depth of -1.60 and -2.00 below the "zero" level. The designer determined the unit load-bearing capacity of the substrate at $\mathrm{q}_{\mathrm{r}}=220 \mathrm{kPa}$, while reserving the need for a commission confirmation of the compliance of the actual conditions with the assumed ones and a possible correction During the verification of the archival materials, no confirmation of the compliance of the 
assumed design parameters in terms of the subsoil with the actual local conditions was found. it had no information confirming the facts, but only unsupported assumptions.
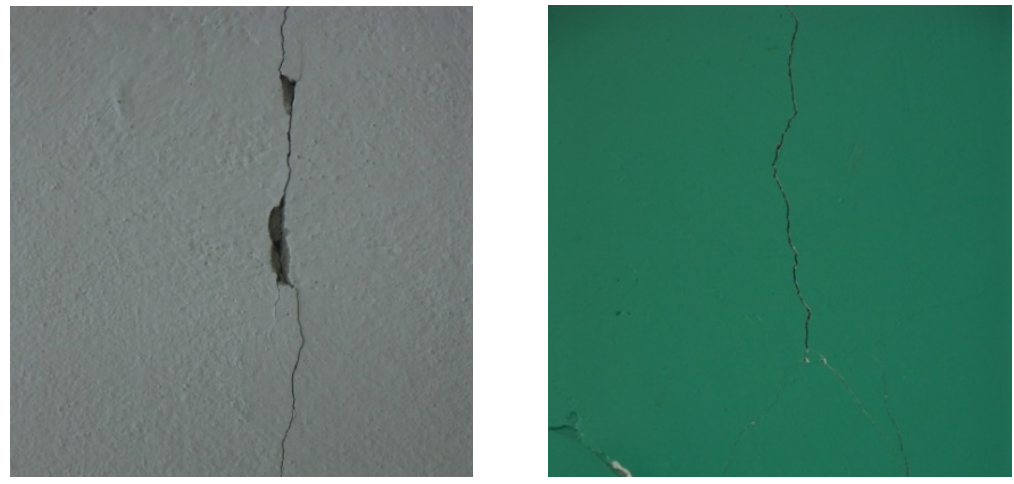

Fig. 2. Examples of scratches revealed during the vision of the object

The main load-bearing system of the hall consists of 7 transverse frames with reinforced concrete columns fixed to the foundation footings and articulated on columns, steel lattice trusses. The frame spacing is $3.0 \mathrm{~m}$. The gable walls are based in the plane of the slope on transverse roof bracing located in the extreme fields. There are also longitudinal roof rails in the extreme fields. The lattice of both N-type braces - the outer strips of the lattice form reinforced concrete cap rings on the walls. The posts and braces of the braces were welded to steel brands concreted in the rims. No additional vertical bracings were made in the walls to transfer the loads from the slope to the foundations.

Internal walls with a thickness of $25 \mathrm{~cm}$ are made of solid ceramic bricks on a cement-lime mortar. The longitudinal wall in the internal axis was made to the ceiling level $(+3.00)$ as a filling between reinforced concrete columns with a cross-section of $30 \times 25 \mathrm{~cm}$. Above the ceiling, up to the level of +5.80 , columns were designed to carry the external wall band together with lattice trusses based on it and a roof full of galleries for viewers. The wall is built on a very low, monolithic reinforced concrete joist (bxh $=52 \times 20 \mathrm{~cm}$ ). From the inside, this wall is scratched in the fields between the columns. Moreover, in the middle of the hall, the inner wall in the inner axis is vertically scratched from the level of the ceiling to the floor. This scratch passes under the support of the corridor floor slabs along the joist. No damage to the reinforced concrete columns was found.

The outer walls of the back-up facility and the connector were made of sandwich panels, made of aerated concrete blocks, type 06 (according to the design), on a cement-lime mortar. Layer arrangement: inside aerated concrete $12 \mathrm{~cm}+5 \mathrm{~cm}$ polystyrene $+12 \mathrm{~cm}$ aerated concrete. Reinforced concrete wreaths insulated with $8 \mathrm{~cm}$ thick polystyrene.

In the longitudinal (northern) wall of the back-up facility, numerous scratches were found along the contact point of the wall with the ceiling, and vertical scratches in the sill walls. Similar cracks are also present in the longitudinal walls of the connector - especially in the northern wall. Vertical features of the back end walls were also found. Scratches are visible from the inside and outside.

Brick gable walls of the gymnasium as above. but with additional reinforced concrete cores with a cross-section of $21 \times 30 \mathrm{~cm}$ and rims with a cross-section of $21 \times 24 \mathrm{~cm}$. The wreaths were made at the level of -0.20 (on the foundation walls), at the level of +2.96 (the ceiling level) and the oblique crown connecting the cap rings of the longitudinal walls.

There were two vertical scratches on both gable walls. The largest cracks occur at the point of connections of the gable walls with the internal longitudinal wall along the internal axis, with the greatest intensity and crack opening at the level of +5.8 . It proves the lack of the rim or the continuity of the structure in this place or the lack of its anchoring in the core and the joist of the longitudinal wall. 
Above the back room and the corridor, a ceiling was made of prefabricated hollow-core slabs of the "Żerański" system. The ceiling is in a transverse arrangement. Typical scratches along the joints of the longitudinal ceiling slabs were found as a result of keyboards.

The back-room ceilings were ventilated and made of closed trough slabs placed on openwork, perforated bricks. The walls are built on the ceiling made of hollow-core slabs. Mineral wool insulation on the ceiling. Roofing felt covers previously obliterated trough tiles.

The roofs above the hall, gallery and connector are made full. On closed (blurred) trough tiles, insulation is made of polystyrene boards $(15 \mathrm{~cm})$, on which a $3 \mathrm{~cm}$ layer of cement screed is applied. The cover is made of 3 layers of asphalt felt on mastic. There are trough tiles based on the walls or strips of the upper truss trusses without any additional topping.

The supporting structure of the roof of the gymnasium is made of steel lattice trusses with a span of $12.0 \mathrm{~m}$, arranged with spacing of every $3.0 \mathrm{~m}$. Parallel chord trusses, articulated on the column heads in the longitudinal walls (support points at different levels - mono-pitched roof). Truss bars are made of isosceles angles connected with gusset plates th. $6 \mathrm{~mm}$. The trusses are braced in the level of the upper chord with lattice braces (N-type grating), transversed at the gable walls and longitudinal ones in the outermost fields. Bracing straps and posts are made of isosceles angles. In 1/4 of the span, a "vertical" longitudinal brace (inclined according to the position of the diagonal) was made along the entire length of the hall (type K grating). The upper strip of this brace is also the strip of the longitudinal slope brace.

It is found that the cross-sections of the posts and diagonals are too small for the adopted type of lattice. In general, too slender bars [slenderness $x>500$ ] were used in all the braces, which causes their buckling and disabling work in the bracing.

Primary errors were revealed related to the improper design of bracings, which are not able to ensure the geometric invariability of the roof slope, buckling stabilization of the truss chords and do not constitute the upper support for the gable walls.

Despite the lack of signs of overload, full verification calculations were performed for the truss. The calculation results, performed with the assumption of stabilization of the upper flange by the roof sheath, showed large exceedances of the load capacity in the upper flange (from 13 to $34 \%$ of the exceedance) and in the pre-extreme diagonals ( $>70 \%$ of the exceedance).

\section{Diagnostics of the causes of failure in the structure of a gymnasium}

As a result of the analysis of the structure's behavior and archival studies, it was found that the repairs to date did not stop the deterioration of the technical condition of the building of the school gymnasium building. In conclusion, it was found that the recommendations for the strengthening of the ground, a very costly micropiling procedure, was completely unsuccessfully, as such solutions are used in the case of intermediate foundations. Certainly, it would be better to use cement injections to strengthen the substrate and limit the suffocation process.

Based on an interview with the administrator of the facility, attention was drawn to the subjective feelings of users related to the behavior of the facility during vehicle traffic on the directly adjacent provincial road. The technical condition of the provincial road was inspected. It was noticed that a pedestrian crossing was located at the height of the building complex, and before the rutting into structural ruts and ending with dents from the set of vehicles was revealed, it is also very important to reveal defects in the pavement and breakthrough in the pavement on the opposite lane.

During the assessment of the object and the condition of the structure, it was noticed that during the passage of truck tractors with semi-trailers, vibrations of the object are felt at the moment of passing by vehicles on the road section with specific failures of the surface condition. The influence of the transferred mechanical waves in an elastic soil medium on the object and on the condition of the structure was recognized $[1,2]$. It was unequivocally recognized that the main destructive factor for the structure is the parasiteismic effect and it was ruled that in order to protect the building, the source of wave propagation should be minimized by damping it with the use of vibro-isolating elements [3]. 


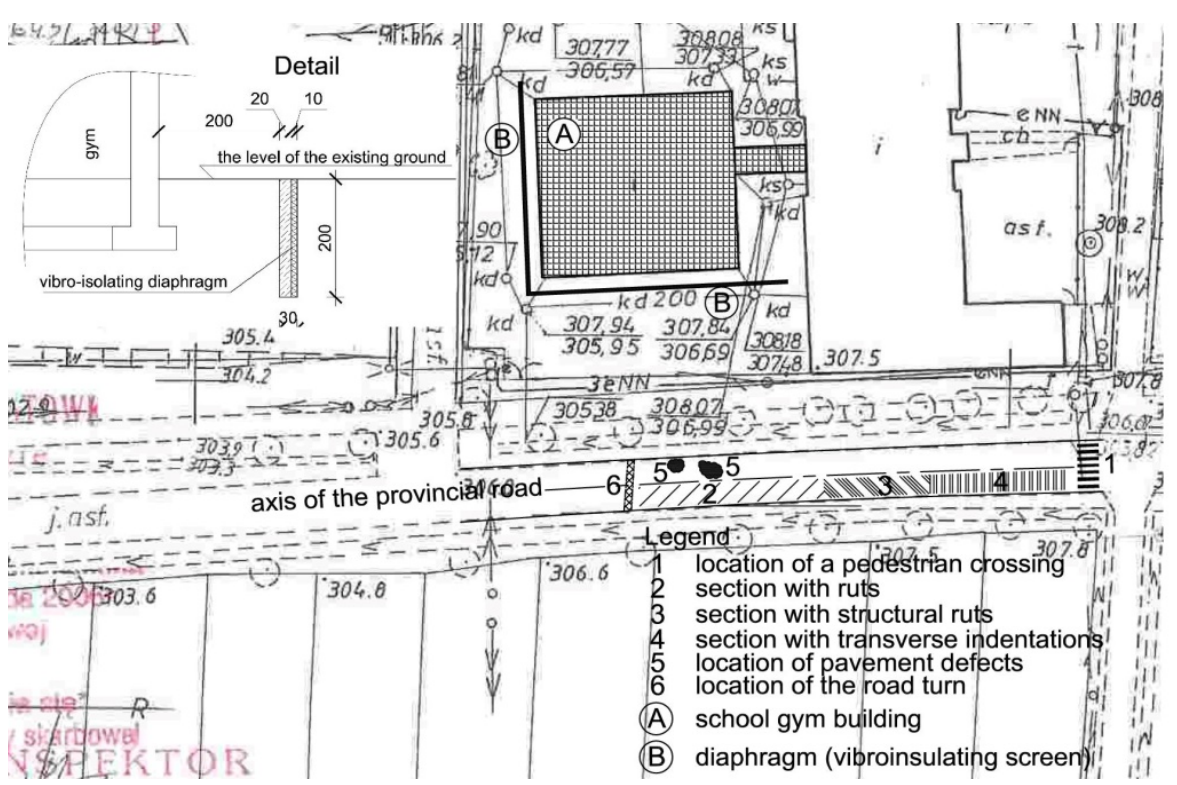

Fig. 3. Graphic description of the surface condition of the voivodeship road and the location of the diaphragm

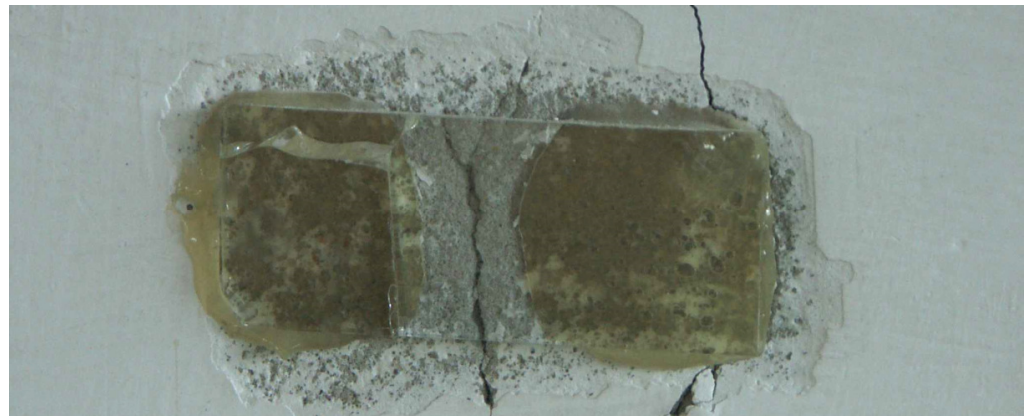

Fig. 4. View of the undamaged seal confirming the deterioration of the structure has been stopped

In order to limit the impact of vibrations resulting from the source of their propagation (the provincial road) and to inhibit the possible suffocation phenomenon, it was recommended to build a diaphragm on the southern side of the building at a distance of $2.0 \mathrm{~m}$ from the building to a depth of $2.0 \mathrm{~m}$ below the ground. It was found that the execution of a reinforced concrete wall with dimensions bxhx $\mathrm{L}=0.20 \times 2.0 \times 55.0(27.0+28.0) \mathrm{m}(\mathrm{W} \times \mathrm{H} \times \mathrm{L})$ and retrofitting the diaphragm with a vibro-insulating layer using $10 \mathrm{~cm}$ of vertical EPS Aqua type insert will effectively solve the problem in question. In addition, the method of scratches and cracks was specified as reinforcement of the wall using steel bars with a diameter of 6 to $8 \mathrm{~mm}$, concreted in grooves cut perpendicular to the crack (preferably in joints, every 2 nd joint). It was recommended to make the length of the furrows to reach a minimum of $50 \mathrm{~cm}$ beyond the fracture. After thorough cleaning of the grooves (e.g. using compressed air) and wetting them thoroughly, it was indicated that they should be filled with a thick cement mortar 1: 3 and a rebar of appropriate length should be inserted into the groove (reinforcement inserts were recommended to be galvanized) [4,5].

After the recommendations were implemented, another inspection was carried out, which confirmed the effectiveness of the designed solution. 


\section{Conclusions}

In the era of dynamic infrastructural development in the field of residential, industrial, public and communication construction, the need to protect people and property against the harmful effects of parasiteismic vibrations was noticed. The urbanized space that surrounds us constantly sends out mechanical waves, which, due to their frequency, length and speed, affect buildings, structures and people in them in various ways.

The Polish Standard PN-B-02170: 2016-12 [6] is a national document related to the assessment of the harmfulness of vibrations transmitted through the ground onto buildings. In terms of its application, we can determine, according to established criteria, the impact of the propagation of mechanical waves propagating in the elastic soil medium on building structures.

On the basis of the conducted analysis, it should be stated that the cited document does not solve the problem of the real impact of vibrations on the environment, as it does not refer to changing conditions in time, as in the presented and analyzed case. The standard does not cover incidental events related to the deterioration of, for example, the technical condition of the road, its operational durability and the actual variable impact of an impact that does not fit into the description of the events.

\section{References}

[1] Major M., Reduction of mechanical wave propagation in a wall made of concrete blocks with rubber filling a numerical analysis, Zeszyty Naukowe Politechniki Częstochowskiej 2019, Budownictwo, 25, 162-167.

[2] Major I., A numerical analysis of the wave phenomena in the spatial structure of a steel grid with a rubber filling, Zeszyty Naukowe Politechniki Częstochowskiej 2019, Budownictwo 25, 157-161.

[3] Hulboj R., Major M., Wybrane aspekty dotyczące posadowień budynków, Zeszyty Naukowe Politechniki Częstochowskiej 2014, Budownictwo 20, 81-88.

[4] Schwegler G., Seismic strengthening of unreinforced masonry buildings with carbon fibers, Publication of Federal Institute of Technology, Zurich, Switzerland, 1995.

[5] Tumialan J.G., Galati N., Namboorimadathil S.M., Nanni A., Strengthening of Masonry with FRP Bars, ICCI 2002 San Francisco, CA, June 10-12.

[6] PN-B-02170:2016-12 - Ocena szkodliwości drgań przekazywanych przez podłoże na budynki.

\section{Analiza szkodliwości wpływu drgań parasejsmicznych na przykładzie awarii konstrukcji budynku przyszkolnej sali gimnastycznej}

\section{STRESZCZENIE:}

Na przykładzie awarii konstrukcji budynku użyteczności publicznej, opisano problematykę związaną $\mathrm{z}$ destrukcyjnym wpływem drgań na podłoże gruntowe w powiązaniu z ustrojem nośnym obiektu. Ustalono zewnętrzne źródło propagacji fal, zlokalizowane w bezpośrednim sąsiedztwie analizowanego budynku. Dodatkowo przedstawiono błędy w interpretacji zachowania konstrukcji w trakcie jej eksploatacji, poprzez wykonywanie nieskutecznych prac budowlanych związanych z próbą wzmocnieniem podłoża gruntowego, na którym w sposób bezpośredni posadowiono przyszkolną salę sportowa. Na podstawie przeprowadzonej analizy materiałów archiwalnych oraz dodatkowych badań określono niezbędny zakres robót naprawczych, koniecznych do wykonania na obiekcie wraz z wytycznymi do realizacji przepony $\mathrm{w}$ formie gruntowego ekranu wibroizolacyjnego, mającego na celu zminimalizowanie wpływu oddziaływań parasejsmicznych na budynek użyteczności publicznej.

\section{SŁOWA KLUCZOWE:}

drgania; propagacja fal; tłumienie fal; wibroizolacja 